\title{
Analysis of Qualities of Construction Wastes as Secondary Material Resources from the Position of the Theory of Stability of Disperse Systems
}

\author{
Vadim Bespalov ${ }^{1}$, Oksana Gurova ${ }^{1}$, Oksana Paramonova ${ }^{1, *}$, Natalia Samarskaya ${ }^{1}$, \\ Ekaterina Lysova ${ }^{1}$, and Natalia Yudina ${ }^{1}$ \\ ${ }^{1}$ Architectural and Construction Academy Don State Technical University, 344022, \\ Sotsialisticheskaya str. 162, Rostov-on-Don, Russia
}

\begin{abstract}
Each type of wastes of different aggregate states coming into the environment from various sources is characterized by certain set of parameters of qualities determining in the future the possibility of their secondary use. The article represents results of innovative research in the sphere of broadening of opportunities of use of construction wastes as secondary material resources. Parameters of qualities of construction wastes created in the process of technological processes at the enterprises of construction industry have been researched and classified. Construction wastes and their qualities are represented from the position of the theory of stability of disperse systems. Physical essence of processes and events was chosen as the main classification criteria in distribution of parameters of qualities of construction wastes by groups. Parameters of qualities of construction wastes are represented for disperse phase and dispersion medium.
\end{abstract}

\section{Introduction}

Purpose of the research is analysis of qualities of construction wastes on basis of application of theory of disperse systems stability from the point of view of broadening of the sphere of their repeated use in economic activity.

For achievement of the set goal the following tasks have been solved:

- generalized parameters of qualities of construction wastes have been systematized;

- their energetic parameters have been researched;

- construction wastes stability has been researched as a resulting criteria representing the waste's capability to resist external influence.

Presently construction of buildings and constructions is carried out with a rather high speed which leads to increase of rates of production of construction wastes, growth of the number

\footnotetext{
Corresponding author: paramonova oh@mail.ru
} 
of demolished old buildings and, as a consequence, the volume of the produced construction wastes grows $[1,2]$.

Nomenclature of wastes created in the construction area of industry includes tens of waste items characterized by various volumes of creation, quantitative and qualitative structure, hazardous characteristics in relation to environment, which complicates their classification, accounting for, collecting and processing [1, 2-4].

Existing classifications of construction wastes are rather different, but one-sided, they do not review the peculiarities of behavior of construction wastes in the environment on each stage of their handling, which could lead to changes of their qualities.

Different approaches to classification of wastes are based on the following classification features: sources of wastes creation; stage of technological process; type of waste; volumes of creation; degree of damage to the environment and human health; direction and efficiency of use; degree of examination and development of the utilization technology [1, 2, 4-10].

Many construction wastes should be utilized, it depends on various parameters allowing to identify 3 categories of wastes:

1 category - wastes created, as a rule, in the beginning of construction (heavy bulk waste, created during the building demolition).

2 category - wastes, created during construction (construction materials packing).

3 category - wastes created during finishing works [8-13].

Besides the classification represented above construction wastes could be divided into:

- raw wastes, source materials wastes being remnants of source materials not changing their main qualities (bark, road metal, keramzit wastes, etc.);

- construction production wastes (scrap brick, ceramic tile scrap, congealed solution, PWM tare, glass scrap, etc.) [1, 4-7, 12].

From the point of view of possibility of use of wastes, as a rule, all wastes, including construction ones, are divided into two flows:

- wastes directed for use as secondary material resources;

- wastes directed finally for burial.

In the majority of cases various trends were developed for use of construction wastes which are determined by physical and chemical qualities of the created wastes, technical opportunities and other factors [1-16]. That is why the issue of examination of qualities of construction wastes is a rather pressing one.

\section{Theory or experimental methods}

Substantial dimensions of creation and accrual of construction wastes lead to environmental pollution of cities and pose pressing issues for the community to lower pollution, as well as develop innovative methods of wastes utilization [1, 2, 4-13, 15-18]. In connection with that description of qualities of wastes should be an important information, preceding the search for solution of these issues.

Existing approaches to examination of qualities of wastes (including construction ones) practically do not reveal the interrelation of characteristics of construction materials, wastes created from them with the characteristics of the environment [14, 17-21].

Processes of formation, division and distribution of construction wastes, as it is known, are explaining the environmental pollution and in the actual conditions could happen either consequently or simultaneously in the space and time [1, 3, 12-14, 17, 18, 20, 22-24]. Thus, they should be reviewed in aggregate, but not separately from each other. Unity of nature of such processes underlines the close interconnection between them. In this case we could speak only of prevalence of the influence of one of the processes. This influence depends 
on the number of parameters, such as qualities of disperse phases (d.p.) and dispersion medium (d.m.) of the waste, characteristics of the environment, etc. [25-29].

Recently number of researches have been suggesting to review any pollutant as a dispersion system [25-29]. Such an approach realizes the theory of dispersion systems based on classical ideas of colloid and physical chemistry. As that in accordance with this approach construction wastes, in our view, in the majority of cases represent a dispersion system made of solid dispersion phase (or several dispersion phases) and gas dispersion medium.

\section{Experimental section}

Methods of examination are based on the main statements of the theory of dispersion systems, system analysis, analytical generalization of the known scientific and practical results.

\section{Results and Discussion section}

Reviewing construction wastes as a dispersion system allows to make a conclusion that the description of their behavior in the environment could be built on basis of complex consequent examination of their state and ordered analysis of parameters, characterizing the qualities of the dispersion phase and dispersion medium.

With this purpose the parameters determining the qualities of dispersion phase (d.p.) and dispersion medium (d.m.) should be groupped taking into consideration physical essence of processes and events in the construction wastes. Analysis of such processes allows to identify the following main groups of parameters (Tab. 1) $[2,3,5,6,10,14,17$, $18,25,27-30]$.

Table 1. Main parameters, identifying qualities of dispersion phase and dispersion medium

\begin{tabular}{|c|c|c|c|}
\hline \multirow{2}{*}{$\begin{array}{l}\text { Ref. } \\
\text { No. }\end{array}$} & \multicolumn{3}{|c|}{ Parameter determining qualities of d.p. and d.m. } \\
\hline & Name & Denomination & $\begin{array}{c}\text { Unit of } \\
\text { measurement }\end{array}$ \\
\hline 1 & 2 & $\mathbf{3}$ & 4 \\
\hline \multicolumn{4}{|c|}{ Parameters of qualities of dispersion phase of a construction waste } \\
\hline \multicolumn{4}{|c|}{ Geometric parameters } \\
\hline 1 & dispersity of waste particles & $d_{(4)}$ & {$[\mathrm{mkm}]$} \\
\hline 2 & specific surface of waste particles & $S_{y \partial}$ & {$\left[\mathrm{m}^{2}\right]$} \\
\hline \multicolumn{4}{|c|}{ Physical-chemical parameters } \\
\hline 3 & pour density of particles & $\rho_{\text {Hac }(u)}$ & {$\left[\mathrm{kg} / \mathrm{m}^{3}\right]$} \\
\hline 4 & rupture strength & $P_{\text {pasp (u) }}$ & {$[\mathrm{Pa}]$} \\
\hline \multicolumn{4}{|c|}{ Hydrodynamic parameters } \\
\hline 5 & wetting angle & $\Theta_{(4)}$ & [degree] \\
\hline 6 & relative humidity & $\varphi_{(4)}$ & {$[\%]$} \\
\hline \multicolumn{4}{|c|}{ Aerodynamic parameters } \\
\hline 7 & particles surface roughness factor & $k_{u}$ & - \\
\hline 8 & dynamic factor of the particles form & $k_{\phi}$ & - \\
\hline \multicolumn{4}{|c|}{$\begin{array}{c}\text { Electromagnetic parameters } \\
\end{array}$} \\
\hline 9 & specific electrical resistance & $R_{y \partial(u)}$ & {$[\mathrm{Ohm} \cdot \mathrm{m}]$} \\
\hline 10 & Material magnetic susceptibility & $\chi$ & - \\
\hline 11 & Internal electrical field intensity & $\frac{\lambda}{E}$ & {$[\mathrm{~V} / \mathrm{m}]$} \\
\hline
\end{tabular}




\begin{tabular}{|c|c|c|c|}
\hline 12 & average charge & $q$ & {$[\mathrm{Kl}]$} \\
\hline \multicolumn{4}{|c|}{ Optic parameters } \\
\hline 13 & refraction index & $n$ & - \\
\hline \multicolumn{4}{|c|}{ Parameters of qualities of dispersion medium of construction waste } \\
\hline \multicolumn{4}{|c|}{ Geometric parameters } \\
\hline 14 & d.m. volume & $V$ & {$\left[\mathrm{~m}^{3}\right]$} \\
\hline \multicolumn{4}{|c|}{ Physical-chemical parameters } \\
\hline 15 & d.m. density & $\rho_{2}$ & {$\left[\mathrm{~kg} / \mathrm{m}^{3}\right]$} \\
\hline \multicolumn{4}{|c|}{ Hydrodynamic parameters } \\
\hline 16 & d.m. humidity (absolute and relative) & $\varphi_{2}$ & [\%] \\
\hline \multicolumn{4}{|c|}{ Aerodynamic parameters } \\
\hline 14 & dynamical air viscosity & $\mu_{2}$ & {$[\mathrm{~Pa} \cdot \mathrm{s}]$} \\
\hline \multirow{2}{*}{\multicolumn{4}{|c|}{ Thermophysical parameters }} \\
\hline & & & {$\left[{ }^{\circ} \mathrm{C}\right]$} \\
\hline
\end{tabular}

Result of the carried out analysis of parameters determining qualities of d.p. and d.m. could be expressed by aggregate of parameters determining qualities of construction wastes in general $(P Q \mathrm{CW})$. In general obtained data could be represented as a functional dependence between groups of parameters of phase components of construction wastes:

$$
P Q_{C W}=f_{1}\left(P Q_{\text {d.p. }}, P Q_{\text {d.m. }}\right)
$$

where $P Q_{d . p .}$ - is the aggregate of parameters determining qualities of d.p. of construction wastes; $P Q_{d . m}$ - is the aggregate of parameters determining qualities of d.m. of construction wastes.

The represented aggregate allows to amend in the process of formation of theoretical bases each group of parameters of d.p. and d.m. with new characteristics and carry out purposeful and consequent evaluation of all sides of the dynamics of creation, accrual, distribution and demolition of construction materials and wastes [25, 27-29].

Purchasing, distribution and consumption of energy of construction materials and wastes is qualitatively characterized by energy parameters which are determined by an interrelated complex of groups of parameters of qualities of d.p. and d.m. of construction wastes.

Energy state of construction wastes will be described by corresponding energy parameters which are characterized by groups of parameters of qualities.

By arrangement of parameters of qualities of d.p. and d.m. of construction wastes from the separated groups the following main energy parameters of construction wastes are formed: kinetic energy $W_{\text {kin. }}$; energy of optical interaction $W_{\text {opt }}$; energy of adhesive interaction $W_{a d h}$; energy of hydrodynamic interaction $W_{h d}$, heat energy $W_{h}$; electromagnetic energy $W_{\text {elect }}$.

The reviewed types of energy in aggregate determine summarized free energy (activation energy) of construction wastes $\left(W_{S} C W\right.$. $)$, which functionally depends on certain energy parameters of d.p. and d.m. of construction wastes which assumes the opportunity of re-distribution of certain types of energy reflecting peculiarities of behavior of construction wastes [25, 27-29].

Having a certain stock of summarized free energy (activation energy) construction materials and wastes show in the environment peculiarities of their behavior which, finally, influences its stability:

$$
W_{S C W} \sim U_{C W} \text {. }
$$

According to modern ideas, stability is a resulting characteristics, determining peculiarities of behavior of dispersion systems, i.e. parameters of their working life. 
Stability is a characteristics of intensity of transformation of parameters of qualities and energy parameters of dispersion system for the certain time interval under the conditions of external influences.

Decrease of stability of dispersion systems is demonstrated either in strengthening of particles of d.p. (re-crystallization), or in adhesion and enlargement of these particles (creation of aggregates is happening) [25, 27-29].

Analysis of parameters characterizing the state of construction wastes as dispersion systems allows to conclude that for description of behavior of construction wastes in the environment as elements of its pollution, as well as for choosing or development of possible technologies for their secondary use, it is necessary to review construction materials and wastes from the position of theory of dispersion systems.

\section{Conclusion}

As the result of the research carried out we have solved the following issues:

- parameters of qualities of construction wastes have been researched and distributed into groups;

- energy parameters of construction wastes have been reviewed;

- stability of construction wastes has been researched.

It will allow in the future to manage the behavior of construction wastes with the purpose of decreasing of their stability and, finally, decreasing of environmental pollution.

\section{References}

1. E. V.Kondrashchenko, A. A. Kachura, Komunal'ne gospodarstvo mist, 107, 150-155 (2013)

2. V.V. Berdus, Stroitel'nye materialy, 2, 31-32 (2001)

3. B.Bossink, H. Brouwers, J. Constr. Eng. Manage, 122(1), 55-60 (1996)

4. C. S.Poon, T. W. Ann, H. Ng L. Resources, conservation and recycling, 32(2), 157-172 (2001)

5. T.B. Tkachenko, Promyshlennoe i grazhdanskoe stroitel'stvo, 8, 35-37 (2011)

6. E.Nikolaeva, Khimicheskiy zhurnal, 4, 34-38 (2003)

7. Kh. S. Vorob'yev, Stroitel'nye materialy, 10, 6-7 (1985)

8. A.G. Yudin, Ekologiya i promyshlennost' Rossii, 3, 229-235 (2010)

9. V. W. Y.Tam, C. M. Tam. A review on the viable technology for construction waste recycling (2006) Resources, Conservation and Recycling, 47 (3), pp. 209-221.

10. P.P.Oleynik, V.I. Brodskiy, Visnik PDABA, 10 (187), (2013) URL: http://cyberleninka.ru/article/n/organizatsiya-upravleniya-pererabotkoy-stroitelnyhothodov (data obrashcheniya: 07.05.2016)

11. N. G. Chumachenko, Vestnik SGASU. Gradostroitel'stvo i arkhitektura, 1, 112-116 (2011)

12. T. Napier, National Institute of Building Science, 25(05), 2013 (2012)

13. A.J Morrissey, J Browne, Waste Management, 24(3), 297-308 (2004)

14. N. G.Chumachenko, Ekologiya i zdorov'ye cheloveka, 201-203 (2001)

15. V. D. Kotlyar, A. V. Ustinov, Internet-zhurnal Naukovedenie, 3(16), (2013) URL: http://cyberleninka.ru/article/n/effektivnaya-stenovaya-keramika-na-osnove-opok-iothodov-ugleobogascheniya (data obrashcheniya: 07.05.2016)

16. Yu. V.Selivanov, V. I.Vereshchagin, A. D.Shil'tsina, Izvestiya TPU, 1, (2004) URL: http://cyberleninka.ru/article/n/poluchenie-i-svoystva-poristoy-stroitelnoy-keramiki (data obrashcheniya: 07.05.2016) 
17. T.O. Kondratenko, A.V. Saybel', IVD, 4 (2), (2012). URL: http://cyberleninka.ru/article/n/otsenka-vozdeystviya-stroitelnogo-proizvodstva-naokruzhayuschuyu-sredu (data obrashcheniya: 07.05.2016)

18. A.S. Grinin, V.N. Novikov, Promyshlennye i bytovye otkhody: Khranenie, utilizatsiya, pererabotka (FAIR-PRESS, Moskva, 2002)

19. O.N. Paramonova, S.O. Koryagin, Stroitel'stvo-2011: Materialy Mezhdunarodnoy nauchno-prakticheskoy konferentsii, 137-139 (2011)

20. L.N. Bel'deeva, Yu.S.Lazutkina, L.F. Komarova, Ekologicheski bezopasnoe obrashchenie s otkhodami, (Azbuka, Barnaul, 2006)

21. I.A.Ryb'yev, Stroitel'noe materialovedenie (Vysshaya shkola, Moskva, 2003)

22. T. A.Sharkov, S. Yu. Efremova, Izvestiya PGU im. V.G. Belinskogo, 29, (2012) URL: http://cyberleninka.ru/article/n/upravlenie-ekologicheskoy-bezopasnostyu-v-oblastisnizheniya-obrazovaniya-othodov-proizvodstva (data obrashcheniya: 07.05.2016)

23. T.O. Kondratenko, A.V. Saybel', IVD, 4 (2), (2012) URL: http://cyberleninka.ru/article/n/ekologicheskaya-otsenka-pri-vybore-stroitelnyhmaterialov-dlya-novogo-stroitelstva-rekonstruktsii-i-restavratsii (data obrashcheniya: 07.05.2016)

24. N. A. Babak, Izvestiya Peterburgskogo universiteta putey soobshcheniya, 3, (2011) URL: http://cyberleninka.ru/article/n/preventivnyy-metod-otsenki-sostoyaniyazaschity-prirodno-tehnogennyh-sistem-i-upravleniya-imi-pri-osuschestvleniistroitelnoy (data obrashcheniya: 07.05.2016).

25. E.P. Lysova., L.A. Lisutina, Malootkhodnye, resursosberegayushchie khimicheskie tekhnologii i ekologicheskaya bezopasnost', 98-100 (2013)

26. S. V. Belov, F. A. Barbinov, A. F. Koz'yakov i dr., Okhrana okruzhayushchey sredy (Vysshaya shkola, Moskva, 1991)

27. V.I. Bespalov, L.Z. Ganicheva, N.V.Yudina, T.L.Pirozhnikova, I.N.Gevorkyants, Biosciences, Biotechnology Research Asia, 11, 27-35 (2014)

28. V.I. Bespalov, O.S. Gurova, N.S. Samarskaya, E.P. Lysova, A.N. Mishchenko, Biosciences Biotechnology Research Asia, 11(3), 1615-1620 (2014)

29. V.I. Bespalov, Izvestiya SKNC VSH. Estestvennye nauki, 37-47 (1995)

30. V.V.Privalenko, I.N.Kuznetsov, S.G. Demchenko, YuNTs RAN, Rostov-na-Donu, (2009) 